J. Product. \& Dev., 21(3): 203-219(2016)

\title{
HEPATOPROTECTIVE AND ANTIDIABITIC EFFECTS OF AQUEOUS Moringa oleifera LEAVES EXTRACT ON EXPERIMENTAL RATS
}

Gehan A. Ghoneim, Faten Y. Ibrahim and Rania E. El-gammal

Food Industries Department, Faculty of Agriculture, Mansoura University, 35516, Mansoura, Egypt.

ABSTRACT

This study was designed to determine the total phenols, flavonoids and antioxidative effect of aqueous Moringa oleifera Leaves extract (AMLE) on the biochemical profile of hepatic dysfunction and diabetic male rats. It was found that AMLE contained $698.82 \mathrm{mg} / \mathrm{g}$ of total phenolic compounds, $26.33 \mathrm{mg} / \mathrm{g}$ of total flavonoids and antioxidant activity (DPPH) recorded $81.6 \%$. Also, the results indicated that e-vanillic acid (1988.32 ppm) and syringic acid (898.25ppm)were the dominant phenolic compounds in AMLE.

Concerning the biological assay, the obtained results showed that there were significant differences between only Lipopolysaccharides (LPS) treated group and those treated with LPS followed by AMLE or AMLE followed by LPS. Where, it could be noticed that there were significant decreases in all liver function values except for serum albumin,which increased and reached to $4.00 \mathrm{mg} / \mathrm{dl}$ in treated group with AMLE followed by LPS. In addition, AMLE improve kidney functions.

Also, antioxidant enzyme concentrations (SOD) increased in treated group with AMLE group followed by treated group with LPS and reached $30.33 \mathrm{U} / \mathrm{L}$. On the other, hand the treatment with AMLE decreased LDL-cholesterol and increased HDL-cholesterol levels at the end of experimental period compared with those of LPS treated group.

As biochemical indices, it could be noticed that blood glucose recorded an improvement in group treated with amaryl drug (167.66 $\mathrm{mg} / \mathrm{dL})$ and AMLE group (180.66 $\mathrm{mg} / \mathrm{dL})$ compared with Streptozotocin (STZ) group (306.66 $\mathrm{mg} / \mathrm{dL})$.

Conclusively, it briefly could concluded that aqueous Moringa olifieria leaves extract had vital effects to prevent LPS induced hepatic dysfunction and gluscose blood level by its high content of polyphenols. Keywords: Moringa oleifera, LPS, STZ, Liver function and Diabetic. 


\section{INTRODUCTION}

Moringa oleifera is one of the most widely cultivated species of monogeneric family Moringaceae, which included around 13 species of trees and shrubs distributed in sub-Himalayan ranges of India, Sri Lanka,Northeastern, South-western Africa Madagascar and Arabia (Fahey, 2005). Moringa trees are an important food commodity as almost all plant parts are edible and consumed as nutritive vegetable in many countries(Oluduro, 2012). Moreover, moringa have long been recognized in the Ayurvedic and Unani systems of medicine for prevention and treatment of several diseases such gastric ulcers, skin diseases, fever, fatigue and bronchitis (Anwar et al., 2007 ).

Liver is a highly sensitive organ which plays a major role in maintenance and performance of the homeostasis in our body. It is the chief organ where important processes like metabolis and detoxification were taken place.Thus liver is proned to injury due to the chronic exposure to drugs, environmental toxicants and other xenobiotics (Amacher, 2002).

Diabetes mellitus is a heterogeneous group of metabolic disorders characterized by glucose intolerance and fasting hyperglycemia (Kantarova et al.,2006). It has become imperative to investigate plants such as Moringa oleifera and Vernonia amygdalina which have been used by native populations as hypoglycaemic agents in a standardized experimentation.

A number of investigations have shown that saponins, flavonoids and other secondary plant metabolites including arginine and glutamic acid possess hypoglycemic effect in various animal models and have been found to be hepatoprotective in diabetic animal experiments (Efiong et al., 2013). This disease is caused by the abnormality in carbohydrate metabolism which could be due to low insulin secretion or insensitivity of target organs to insulin (Sugunabai et al., 2014).

Therefore, this study was aimed to evaluate the hepatoprotective activity and the antidiabetic effect of aqueous Moringa oleifera leaves extract on male albino rats.

\section{Materials :}

\section{MATERIALS AND METHODS}

Moringa oleifera leaves were collected from Faculty of Agriculture Farm, Mansoura University, El- Mansoura, Egypt. 
Lipopolysaccharides LPS (LPS from E.coli 055 B5; Difco, Detroit, MI and Streptozotocin (STZ ) were obtained from Sigma Aldrich Chemicals, St., Louis, MO, USA. Amaryl drug is oral hypoglycemic drug producing by SaofiAvents, Egypt.

\section{Expermintal rats:}

Forty (40) male Albino rats of $(250 \pm 10 \mathrm{~g})$ were purchased from animal house, Faculty of Pharmacy, Mansoura University, Egypt.

\section{Methods:}

Preparation of Moringa oleifera leaves powder :

Moringa leaves were washed using tap water and dried using hot air oven at $55^{\circ} \mathrm{C}$ for 12 hours. Dried leaves were milled, sieved (60 mesh) and packed into tight polyethylene bags until using and analysis.

\section{Aqueous moringa leaves extract (AMLE):}

$10 \mathrm{~g}$ of dried moringa leaves powder were added to $750 \mathrm{ml}\left(90^{\circ} \mathrm{C}\right)$ distilled water for $3 \mathrm{~min}$, filtered, cooled and was ready to use for biological assay.

\section{Determination of total phenolic compounds and total flavonoids:}

Folin-Ciocalteu method was used to determine of total phenolic compounds (as gallic acid) using standardized spectrophotometric according to Ivanova et al.,(2010) and Flavonoids were extracted and estimated by the method described by A.O.A.C. (2000).

\section{Determination of Radical Scavenging Activity (DPPH\%):}

2,2 diphenyl1-picrylhydrazyl (DPPH \%) assay was carried out according to the method described by Brand-Williams et al., (2000).

\section{Identification of phenolic compounds:}

Phenolic compounds fractionated and identified, by HPLC according to the method described by Goupy et al., (1999).

\section{Biological assay:}

Animals and experimental design:

The study was performed on male albino rats $(250 \pm 10 \mathrm{~g})$. All animals were kept under standardized conditions (12h light/ dark cycle, $22 \pm 2^{\circ} \mathrm{C}$ ) and were provided free access to basal diet (Table1) and water (NRC, 1995). Rats were fed on basal diet for 7 days before the beginning of the experiment for adaptation. 
Table 1. Composition of the basal diet.

\begin{tabular}{|l|c|}
\hline \multicolumn{1}{|c|}{ Ingredients } & g./kg diet \\
\hline Casein & 200 \\
\hline Corn starch & 497 \\
\hline Sucrose & 100 \\
\hline Vitamin mixture & 20 \\
\hline Mineral mixture & 100 \\
\hline Corn oil & 50 \\
\hline Cellulose & 30 \\
\hline Methionine & 3 \\
\hline
\end{tabular}

\section{Experimental design :}

After adaptation period the animals were randomly divided into two main groups of 20 rats each.

Group A (GA): This experiment was designated to study the therapeutic effect of aqueous moringa leaves extract on lipopolysaccharide (LPS) induced hepatic dysfunction in rats. In this experiment, twenty male rats were divided into four groups $(n=5)$ and one of them was kept as a normal control group. Rats were injected with a sub lethal intraperitoneal dose of crude lipopolysaccharides $(10 \mu \mathrm{g} / \mathrm{kg} / \mathrm{bw})$. dissolved in $0.5 \mathrm{ml}$ of sterile, pyrogen-free $0.9 \%$ sodium chloride (saline) for 24 hours only (Kemelo et al., 2014).

The groups shows as follows:

GA1:Normal control group: Fed on basal diet and injected under cutaneous $0.9 \% . \mathrm{NaCl}$.

GA2:LPS control group: Fed on basal diet and treated with LPS (for 24 hours only).

GA3:LPS followed by AMLE group: Fed on basal diet and treated with LPS (for 24 hours only) and given aqueous moringa leaves extract instead of drinking water.

GA4:AMLE followed by LPS group: Fed on basal diet and given aqueous moringa leaves extract instead of drinking water for 29 days and after that reated with LPS(for 24 hours only).

Blood samples were collected at the end of experiment 30 days from the eye plexuses by fin capillary glass tubes into a dry clean centrifuged glass tube to prepare the serum. Blood samples were left $15 \mathrm{~min}$ at room temperature then the tubes were centrifuged for $10 \mathrm{~min}$ at $3000 \mathrm{rpm}$ and supernatant was kept frozen at $-80{ }^{\circ} \mathrm{C}$. 
Group B (GB): This experiment was designated to study the therapeutic effect of aqueous Moringa oleifera leaves extract on plasma glucose in (STZ) streptozotocine-induced diabetic rats. In this experiment, twenty male rats were divided into four groups $(\mathrm{n}=5)$ and one of them was kept as a normal control group. Rats were subjected to streptozotocine dissolved in cold $0.01 \mathrm{M}$ citrate buffer, streptozotocine was intraperitoneally given at dose $65 \mathrm{mg} \mid \mathrm{kg}$ body weight to induce diabetes. After injection, rats were supplied with $5 \%$ glucose solution for 48 hours Broca et al., (1999) and when animals showing fasting blood glucose more than $300 \mathrm{mg} / \mathrm{dl}$ there were used as diabetic rats.

The groups shows as follows:

GB1:Normal control group: Fed on basal diet and received distilled water (2.5mllkg).

GB2:Diabetic group: Diabetic rats fed on basal diet and received distilled water $(2.5 \mathrm{mllkg})$.

GB3: Moringa group: Diabetic rats fed on basal diet and received aqueous moringa leaves extract instead of drinking water.

GB4: Amaryl drug group: Diabetic rats fed on basal diet and received Amaryl drug ( daily dose was $0.36 \mathrm{mg} \mid \mathrm{kg}$ body weight) by dissolving in distilled water (Paget and Barnes, 1964).

At the end of four weeks, the animals were deprived of food overnight and blood was collected from the eye plexuses by fin capillary glass tubes into a dry clean glass using EDTA as anticoagulant. The whole blood was used for the estimation of glucose.

Biochemical analysis:

Liver function: Serum aspartate amino-transferase (AST) and alanine aminotransferase (ALT)concentrations were determined according to Reitman and frankel (1957). Alkaline phosphate (ALP) was determined according to Wenger et al., (1984) .Bilirubin was determined by the method described by Kaplan and Murphy (1984), and albumin was determined according to Doumas et al., (1971).

Antioxidant enzymes: Superoxide dismutase (SOD) was determined by Oyanatui (1984).

Kidney functions: Serum creatinine as estimated by Fabiny and Eringhausen, (1971), blood urea were determined using colorimetric method described by Tabacco et al.(1979).

Lipid profile: Total cholesterol (TC),Triglycerides (TG), low density lipoprotein (LDL-c) and high density lipoprotein cholesterol ( HDL-c ) were 
determined by the methods of Roeschlau, et al., (1974) and Fossati and Prencipel (1982), respectively.

Serum glucose: Blood glucose was estimated by an enzymatic colorimetric method according to Siest et al. (1981).

Glucose tolerance test:After 4 weeks of treatment (on the $29^{\text {th }}$ day), fasting blood sample was taken from all experimental rats. Blood samples were collected at four tiems 30, 60, 90, and 120 mins. intervals (Whittington et al., 1991) after administration of glucose at $2 \mathrm{~g} / \mathrm{kg}$ body weight (Pari, and Umamaheswari 1999). All the blood samples were collected with potassium oxalate and sodium fluoride solution for the estimation of blood glucose according method described by Pencock et al. (1973).

\section{Statistical analysis:}

Data were presented as mean $\pm \mathrm{SD}(\mathrm{n}=3)$. Data were analyzed using analysis of variance (two ways ANOVA), while comparisons were made using Duncan's test at $P<0.05$ level of significance using SPSS (2008) version 17 program for windows.

\section{RESULTS AND DISCUSSIONS}

Total phenolic compounds, total flavonoids contents and radical scavenging activity of moringa leaves powder:

From results presented in Table (2), it could be noticed that the total phenolic content as gallic acid was $698.82 \mathrm{mg} / \mathrm{g}$ and total flavonoids was $26.33 \%$. These results are in agreement with those obtained by Abdul Karim et al ., (2005) who found that total phenolic content (TPC) of Moringa oleifera leaves extract was ranged from 590 to $690 \mathrm{mg} / \mathrm{g}$ and total flavonoids (TFC) was $22.3 \%$.Data in the same Table (2) showed also that moringa leaves extract observed antioxidant activity (DPPH) of $81.6 \%$.These results were higher than those obtained by Pakade et al .,(2013) and Santos et al ., (2012), they stated that Moringa leaves have antioxidant activity ranged from 55.1 to $71.5 \%$ these difference in the antioxidant activity could be due the agro climatic conditions.

Fractionation and identification of Phenolic compounds of moringa leaves powder:

The results presented in Table (3) show that phenolic compounds content of moringa leaves ranged from $3.32 \mathrm{ppm}$ to $1988.32 \mathrm{ppm}$. It clearly 
Table 2. Total phenolic compounds, total flavonoids contents and Radical scavenging activity of moringa leaves powder.

\begin{tabular}{|c|c|c|c|}
\hline Samples & $\begin{array}{c}\text { Total phenolic } \\
\text { compound } \\
\text { as gallic acid(mg/g) }\end{array}$ & $\begin{array}{c}\text { Total flavonoids } \\
(\mathbf{m g} / \mathrm{g})\end{array}$ & $\begin{array}{c}\text { Radical scavenging } \\
\text { activity } \\
\text { (DPPH \%) }\end{array}$ \\
\hline $\begin{array}{c}\text { Moringa } \\
\text { leaves powder }\end{array}$ & $\mathbf{6 9 8 . 8 2}$ & $\mathbf{2 6 . 3 3}$ & $\mathbf{8 1 . 6}$ \\
\hline
\end{tabular}

Table 3. Phenolic compounds (ppm) in moringa leaves powder.

\begin{tabular}{|l|c|}
\hline Phenolic Compounds in moringa leaves powder & ppm \\
\hline Syringic acid & 898.25 \\
\hline Gallic acid & 7.87 \\
\hline Pyrogallol & 515.32 \\
\hline 4-amino- benzoic acid & 3.32 \\
\hline Catechein & 63.23 \\
\hline Chlorogenic acid & 40.76 \\
\hline Catechol & 50.65 \\
\hline Caffeine & 111.21 \\
\hline p-OH-benzoic acid & 76.03 \\
\hline Caffeic acid & 44.31 \\
\hline Vanillic acid & 50.11 \\
\hline Ferulic acid & 15.09 \\
\hline Iso-Ferulic acid & 22.03 \\
\hline e-vanillic acid & 1988.32 \\
\hline Ellagic acid & 89.91 \\
\hline Alpha-coumaric acid & 7.85 \\
\hline Benzoic acid & 920.3 \\
\hline
\end{tabular}

that e-vanillic acid was the most predominant component, (1988.32 ppm) followed by benzoic acid and syringic acid (920.3and 898.25 ppm, respectively). While 4-amino- benzoic acid, alpha-coumaric acid and gallic acid were recorded the lowest content of phenolic compounds $(3.32,7.85$ and $7.87 \mathrm{ppm}$, respectively). These compounds will be the way for understanding their action mechanism to exploit their potential as antioxidants and therapeutic applications (Berger et al., 2013; Chen and Chen, 2013; Chen et al., 2013). Some authors reported that Some hydroxycinnamates phenolic compounds such as caffeic, ferulic or p-coumaric acids have a positive effect to protect LDL-c particles against oxidation in vitro, (Guy et al., 2009). 


\section{Biological assay: \\ Liver functions:}

Table (4) summarized effect of Moringa oleifera leaves extract on liver functions (ALT, AST, ALP, billiurbin and albumin ) levels in LPS induced hepatotoxicity in male rats.Tabulated data in Table (4) show that as a result of LPS treated group ALT and AST sharply increased from 26.33 and 92.66 IU/L to 62.00 and 204.00 IU/L, respectively. Moringa leaves extract reduced these value to 38.67 and 120.33 IU/L in AMLE followed by LPS group and to 48.00 and 144.33 IU/L in LPS followed by AMLE group, respectively. While, alkaline phosphate (ALP ) content ranged from 165.33 IU/L in normal control group to 266.00 IU/L LPS control group.

Table 4. Effect of aqueous Moringa oleifera leaves extract on the ALT, AST, ALP, bilirubin and albumin activities in rats.

\begin{tabular}{|c|c|c|c|c|c|}
\hline Parameters & $\begin{array}{c}\text { ALT } \\
\text { (IU/L) }\end{array}$ & $\begin{array}{c}\text { AST } \\
\text { (IU/L) }\end{array}$ & $\begin{array}{c}\text { ALP } \\
\text { (IU/L) }\end{array}$ & $\begin{array}{c}\text { Bilirubin } \\
\text { (mg/dl) }\end{array}$ & $\begin{array}{c}\text { Albumin } \\
(\mathbf{g} / \mathbf{d l})\end{array}$ \\
\hline \multirow{2}{*}{ GA1 (Normal control) } & $26.33 \pm$ & 92.66 & 165.33 & 0.34 & 4.30 \\
& $3.21^{\mathrm{a}}$ & $\pm 6.93^{\mathrm{a}}$ & $\pm 9.02^{\mathrm{a}}$ & $\pm 0.04^{\mathrm{a}}$ & $\pm 0.15^{\mathrm{c}}$ \\
\hline \multirow{2}{*}{ GA2 (LPS control) } & 62.00 & 204.00 & 266.00 & 0.99 & 2.83 \\
& $\pm 3.21^{\mathrm{c}}$ & $\pm 10.11^{\mathrm{c}}$ & $\pm 10.26^{\mathrm{ab}}$ & $\pm 0.08^{\mathrm{b}}$ & $\pm 0.15^{\mathrm{a}}$ \\
\hline GA3(LPS followed by & 48.00 & 144.33 & 210.00 & 0.64 & 3.63 \\
AMLE) & $\pm 2.64^{\mathrm{b}}$ & $\pm 8.45^{\mathrm{b}}$ & $\pm 8.38^{\mathrm{b}}$ & $\pm 0.04^{\mathrm{b}}$ & $\pm 0.88^{\mathrm{b}}$ \\
\hline GA4(AMLE followed & 38.67 & 120.33 & 183.67 & 0.62 & 4.00 \\
by LPS) & $\pm 3.38^{\mathrm{ab}}$ & $\pm 11.46^{\mathrm{ab}}$ & $\pm 7.21^{\mathrm{c}}$ & $\pm 0.14^{\mathrm{c}}$ & $\pm 0.12^{\mathrm{bc}}$ \\
\hline
\end{tabular}

Means of treatments having the same letter(s) within a colum are not significantly different $(\mathrm{P}>0.05)$. Where, LPS: lipopolysaccharide ; AMLE: Aqueous Moringa oleifera leaves extract.

As bilirubin concentration, it significantly increased while albumin content significantly decreased in the rats serum that received lipopolyscharide (LPS) compared with normal control group. In the rats that received AMLE followed by LPS, protective effects were observed by observing bilirubin rate lower $(0.62 \mathrm{mg} / \mathrm{dl})$ and slight increase in albumin $(4.00 \mathrm{~g} / \mathrm{dl})$ as compared with the rats that received only LPS (Table 4). The mentioned results confirmed that chronic lipopolysaccharide (LPS), causes liver dysfunction and toxicity by significant changes in cells damage and antioxidant parameters of rat liver. These results were in good agreement with those of Thiemermann et al., (1995), who reported that rats injected with LPS for $6 \mathrm{~h}$ were associated with a significant rise in the serum levels of a GOT or GPT and bilirubin, and 
hence, liver dysfunction. Also, obtained results are in concomitant with those of Liu et al., (2008), who observed that blood biochemistry indices, including those of alanine aminotransferase (ALT), aspartate aminotransferase (AST) and total bilirubin (TBIL), had risen by $6 \mathrm{~h}$ post-LPS/D-GalN injection, reached a peak after $24 \mathrm{~h}$ and sustained high levels after $48 \mathrm{~h}$. An abnormal liver appearance was found after 24 and $48 \mathrm{~h}$ post-injection.

\section{Kidney functions:}

Data in Table (5) show that creatinine content was increased from 0.53 to $1.06 \mathrm{IU} / \mathrm{L}$ for normal control group and LPS control group, respectively. Moringa leaves extract reduced this value to 0.72 and $0.87 \mathrm{IU} / \mathrm{L}$ for AMLE followed by LPS group and LPS followed by AMLE group, respectively. While, results show urea levels was significantly different $(\mathrm{P}<0.05)$ in all groups. LPS control group has the highest urea level (54.00 IU/L) followed by group treated with LPS followed by AMLE group (39.66 IU/L) and AMLE followed by LPS group 23.67 IU/L copared with normal control group (18.67 IU/L).

Table 5. Effect of aqueous Moringa oleifera leaves extract on kidney function in rats.

\begin{tabular}{|c|c|c|}
\hline Groups $\quad$ Parameters & $\begin{array}{l}\text { Creatinine } \\
(\text { IU/L) }\end{array}$ & $\begin{array}{c}\text { Urea } \\
(\text { IU/L) }\end{array}$ \\
\hline GA1 (Normal control) & $\begin{array}{c}0.53 \\
\pm 0.03^{\mathrm{a}}\end{array}$ & $\begin{array}{c}18.67 \\
\pm 2.33^{\text {a }}\end{array}$ \\
\hline GA2 (LPS control) & $\begin{array}{c}1.06 \\
\pm 0.66^{\mathrm{c}}\end{array}$ & $\begin{array}{c}54.00 \\
\pm 6.24^{\mathrm{c}}\end{array}$ \\
\hline GA3 (LPS followed by AMLE) & $\begin{array}{c}0.87 \\
\pm 0.05^{c}\end{array}$ & $\begin{array}{r}39.66 \\
\pm 3.52^{\mathrm{b}}\end{array}$ \\
\hline GA4 (AMLE followed by LPS) & $\begin{array}{c}0.72 \\
\pm 0.02^{\mathrm{b}}\end{array}$ & $\begin{array}{l}23.67 \\
\pm 2.40^{\text {a }}\end{array}$ \\
\hline
\end{tabular}

Means of treatments having the same letter(s) within a colum are not significantly different $(\mathrm{P}>0.05)$. Where, LPS: lipopolysaccharide ; AMLE: Aqueous Moringa oleifera Leaves extract.

\section{Antioxidant enzymes:}

The activities of superoxide dismutase (SOD) was estimated using colorimetric method in the serum of rat groups treated with LPS, LPS followed by AMLE, AMLE followed by LPS and compared with normal control group (Table 6). Significant decreases in the activities SOD were oceurred in LPS group compared with normal control group where, it represented 13.67U/L. 
However in group of rats treated with AMLE followed by LPS and LPS followed by AMLE, the antioxidant properties of aqueous moringa leaves extract and its high free radical scavenging activity produced significant increases in superoxide dismutase (SOD) activity compared with LPS treated group where, they recorded 30.33 and $22.33 \mathrm{U} / \mathrm{L}$, respectively.Obtained findings were in parallel with those of Angela et al. (1999) who reported statistically significant decrease in the activities of SOD, catalase, Glutathione (GSH), and GSHPx after 24, 48, and 72 hours following LPS endotoxin administration and remained lower than those of controls for the duration of the study and concluded that the changes in the conjugative enzymes and the free-radical scavenging enzymes following endotoxin exposure may alter the host's metabolism and response to free radicals.

Table 6. Effect of aqueous Moringa oleifera leaves extract on SOD activity in rats.

\begin{tabular}{|c|c|c|c|c|}
\hline $\begin{array}{c}\text { Groups } \\
\text { Parameter }\end{array}$ & $\begin{array}{c}\text { GA1 } \\
\text { (Normal } \\
\text { control) }\end{array}$ & $\begin{array}{c}\text { GA2 } \\
\text { (LPS } \\
\text { control) }\end{array}$ & $\begin{array}{c}\text { GA3 } \\
\text { (LPS followed by } \\
\text { AMLE) }\end{array}$ & $\begin{array}{c}\text { GA4 } \\
\text { (AMLE followed by } \\
\text { LPS) }\end{array}$ \\
\hline \multirow{2}{*}{ SOD(U/L) } & 37.33 & 13.67 & 22.33 & 30.33 \\
& $\pm 1.86^{\mathrm{d}}$ & $\pm 1.20^{\mathrm{a}}$ & $\pm 1.76^{\mathrm{b}}$ & $\pm 1.45^{\mathrm{c}}$ \\
\hline
\end{tabular}

Means of treatments having the same letter(s) within a colum are not significantly different $(\mathrm{P}>0.05)$. Where, LPS: lipopolysaccharide ; AMLE: Aqueous Moringa oleifera Leaves extract

\section{Lipids profile:}

The results in Table (7) show the effect of aqueous moringa leaves extract on total cholesterol(TC), triglycerides (TG), LDL-c, and HDL-c of normal and treated rats groups. From the obtained data, it could be observed that, levels of total cholesterol(TC) of groups treated with aqueous moringa leaves extract were decreased significantly from 126.66 to $96.00 \mathrm{mg} / \mathrm{dl}$ in LPS control group and AMLE followed by LPS group, respectively. While the triglycerides in blood serum recorded $73.33 \mathrm{mg} / \mathrm{dL}$ in normal control group. Also it was observed that treated rats with LPS only cused significantly increased in blood triglycerides levels which recorded106.33 $\mathrm{mg} / \mathrm{dl}$. While treated rats with aqueous moringa leaves extract reduced significantly blood triglycerides levels compared with those of LPS group (80.67 and $92.00 \mathrm{mg} / \mathrm{dl}$ ) for (AMLE followed by LPS and LPS followed by AMLE groups, respectively).

Concerning the results of LDL-cholesterol at the end of experimental period, was decreased in groups treated with AMLE followed by LPS and LPS 
Table 7. Effect of aqueous leaves extract of Moringa oleifera on lipid profile.

\begin{tabular}{|c|c|c|c|c|}
\hline $\begin{array}{ll}\text { Groups } & \text { Parameters } \\
\end{array}$ & $\begin{array}{c}\mathrm{TC} \\
\mathrm{mg} / \mathrm{dl}\end{array}$ & $\begin{array}{c}\text { TG } \\
\mathrm{mg} / \mathrm{dl}\end{array}$ & $\begin{array}{l}\text { LDL-c } \\
\text { mg/dl }\end{array}$ & $\begin{array}{c}\text { HDL-c } \\
\text { mg/dl }\end{array}$ \\
\hline GA1 (Normal control) & $\begin{array}{r}86.66 \\
\pm 3.17^{\mathrm{a}} \\
\end{array}$ & $\begin{array}{r}73.33 \\
\pm 2.18^{\mathrm{a}} \\
\end{array}$ & $\begin{array}{l}48.67 \\
\pm 3.75^{\mathrm{a}} \\
\end{array}$ & $\begin{array}{r}23.33 \\
\pm 0.88^{\mathrm{c}} \\
\end{array}$ \\
\hline GA2 (LPS control) & $\begin{array}{l}126.66 \\
\pm 6.38^{c}\end{array}$ & $\begin{array}{l}106.33 \\
\pm 6.11^{\mathrm{c}}\end{array}$ & $\begin{array}{l}90.67 \\
\pm 6.923^{c}\end{array}$ & $\begin{array}{r}15.33 \\
\pm 1.76^{\mathrm{a}}\end{array}$ \\
\hline GA3 (LPS followed by AMLE) & $\begin{array}{r}114.00 \\
\pm 7.93^{\mathrm{bc}}\end{array}$ & $\begin{array}{r}92.00 \\
\pm 5.29^{\mathrm{b}}\end{array}$ & $\begin{aligned} & 77.00 \\
\pm & 8.386^{\mathrm{bc}}\end{aligned}$ & $\begin{array}{c}18.67 \\
\pm 1.45^{\mathrm{ab}}\end{array}$ \\
\hline GA4 (AMLE followed by LPS) & $\begin{array}{c}96.00 \\
\pm 4.72^{\mathrm{ab}}\end{array}$ & $\begin{array}{c}80.67 \\
\pm 1.20^{\mathrm{ab}}\end{array}$ & $\begin{array}{c}58.00 \\
\pm 5.686^{\mathrm{ab}}\end{array}$ & $\begin{array}{l}21.67 \\
\pm 1.20^{\mathrm{bc}}\end{array}$ \\
\hline
\end{tabular}

Means of treatments having the same letter(s) within a colum are not significantly different $(\mathrm{P}>0.05)$. Where, LPS: lipopolysaccharide ; AMLE: Aqueous Moringa oleifera Leaves extract

followed by AMLE (58.00 and $77.00 \mathrm{mg} / \mathrm{dl}$, respectively). While LPS group was recorded the highest blood LDL-cholesterol level $(90.67 \mathrm{mg} / \mathrm{dl})$ in compeared with other groups.. On the contrary, the groups which treated with AMLE followed by LPS and LPS followed by AMLE increased in HDLcholesterol levels compeared with LPS group and reach its highest level in normal control group $(23.33 \mathrm{mg} / \mathrm{dl})$. These results are in agreement with those of Pratik, (2013).

\section{Blood glucose:}

Figure (1) shows the levels of blood glucose in all exprimental rats groups. Blood glucose had the lowest value $(83.33 \mathrm{mg} / \mathrm{dL})$ in control group and recorded the highest value $(306.66 \mathrm{mg} / \mathrm{dL})$ in diabetic group. Meanwhile, it relatively decreased in group treated with amaryl drug and aqueous moringa leaves extract treated diabetic rats groups with value of 180.66 and $167.66 \mathrm{mg} / \mathrm{dL}$, respectively. These last results were promising to use aqueous moringa leaves extract to improve blood sugar of diabetic patients. Moringa hypoglycemic activity is reported to be due to the presence of $\alpha$-glucosidase and pancreatic amylase enzyme inhibitors (Abdul Karim et al., 2005).

\section{Changes of blood glucose:}

Figure (2) shows the levels of blood glucose of present experimental groups rats after oral administration of glucose. In diabetic control rats, serum plasma glucose concentration was increased during 1 hour then it deceased in the next hour. 


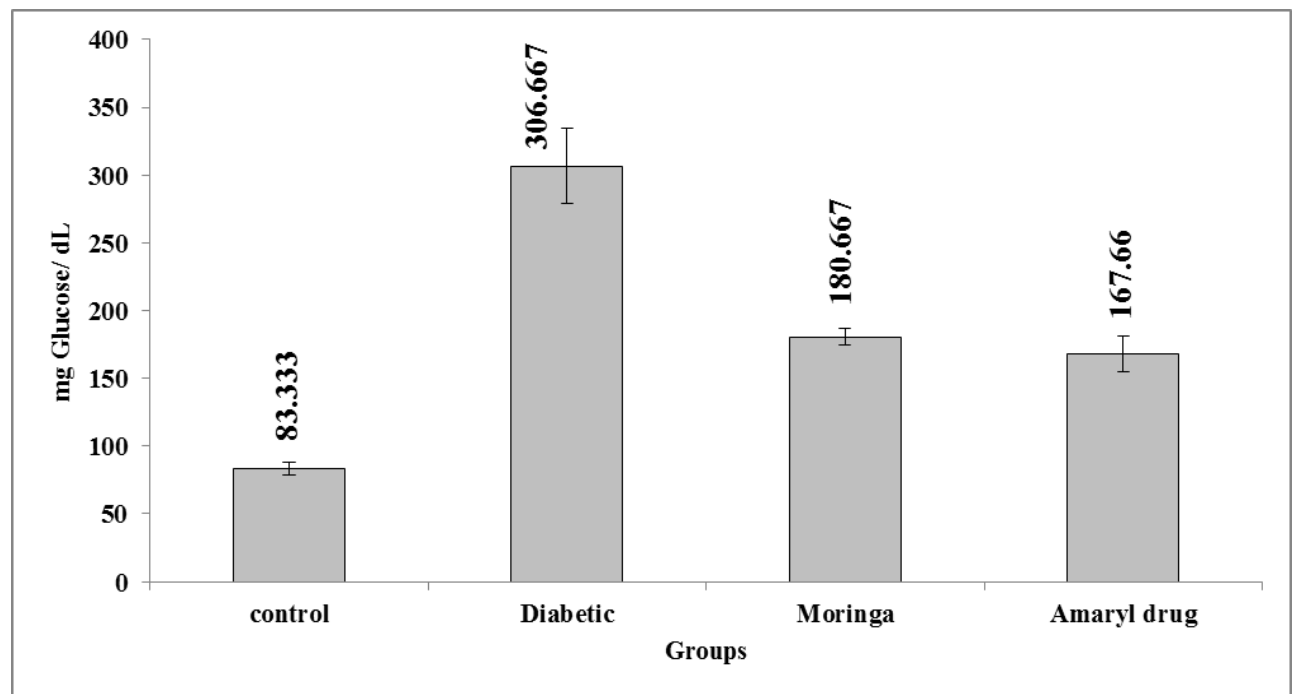

Figure (1): Effect of aqueous Moringa oleifera Leaves extract and Amaryl drug on blood glucose $(\mathrm{mg} / \mathrm{dL})$ in exprimental rats.

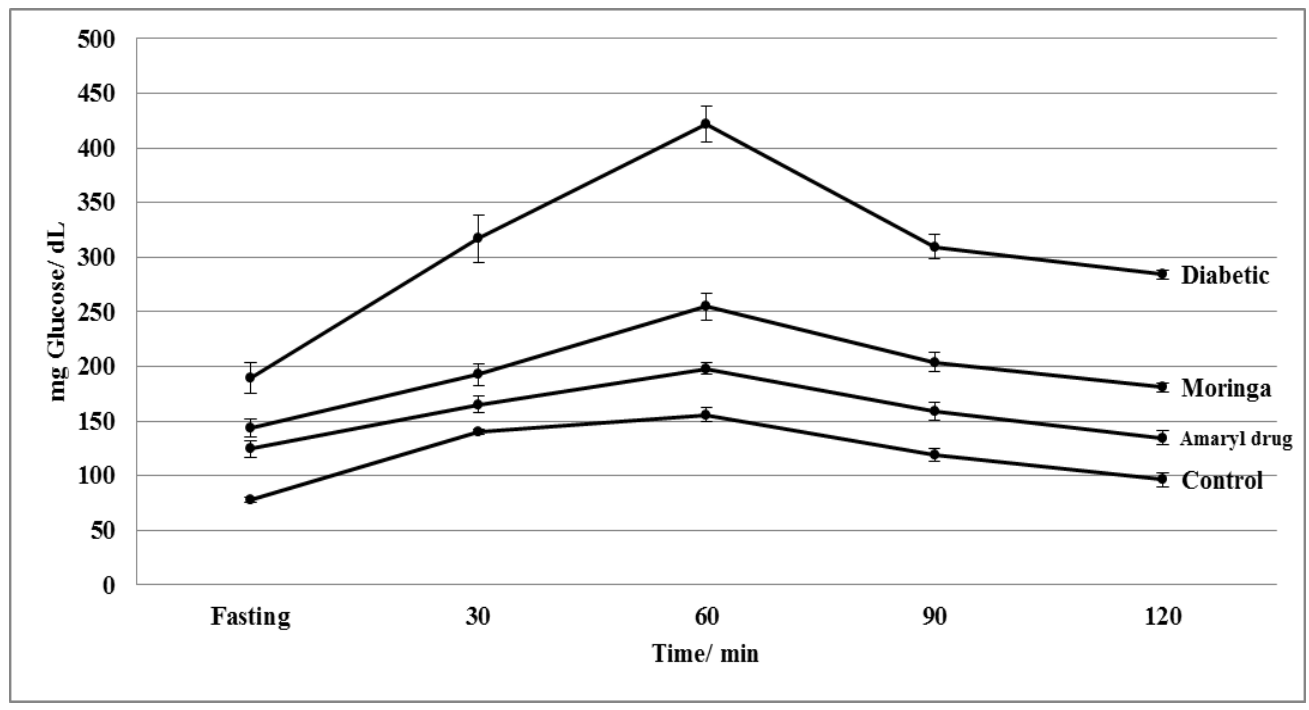

Figure (2): Changes of blood glucose $(\mathrm{mg} / \mathrm{dL})$ in exprimental rats as affected by fasting time (glucose tolerance).

Amaryl drug treated diabetic rats showed significant decrease in blood glucose concentration at 1 st hour and 2 ed hours glucose tolerance when compared with diabetic control rats. While in aqueous moringa leaves extract 
treated rats, blood glucose levels was decreased at 1st hour and 2ed hours glucose tolerance when compared with diabetic control rats. The glucose tolerance effect was more pronounced after a 1-hour interval. The aqueous extract of leaves of Moringa oleifera has shown to lower the blood sugar in diabetic rats ( Ndong et al.,2007).

Conclusively, from obtained results, it briefly could concluded that aqueous Moringa olifieria leaves extract had vital effects to prevent LPS induced hepatic dysfunction and gluscose blood level by its high content of polyphenols.

\section{REFERENCES}

A.O.A.C.(2000). Official Methods of Analysis. Association of Official Analytical Chemists. Washington, DC, USA.

Abdul Karim, S. M.; Long, K.;Lai O. M.; Muhammad, S. K. S. and Ghazali, H.M. (2005). Some physico-chemical properties of Moringa oleifera seed oil extracted using solvent and aqueous enzymatic methods. Food Chem., 93:253-263.

Amacher, D.E. (2002). Toxicologist's Guide To Biomarkers Of Hepatic Response. Hum Exp. Toxicol., 21(5): 253 -262.

Angela, M. W.; Graham, W.; Georgette, H.; Steven, I. S. and Robert, A. B. (1999). Activities of conjugating and antioxidant enzymes following endotoxin exposure. J. Biochem. Toxicol., 13: 63-69.

Anwar,F.; Latif, S.; Ashraf, M. and Gilani, A. H. (2007). Moringa oleifera :A food plant with multiple medicinal uses. Phytother. Res., 21:17-25.

Berger, A.; Venturelli, S.; Kallnischkies, M.; Busch, C.; Weiland, T.; Noor, S., Leischner, C., Weiss, T.S., Lauer, U.M., Bischoff, S.C. and Bitzer, M., (2013). Kaempferol, a new nutrition-derived paninhibitor of human histone deacetylases. J. Nutr. Biochem., 24: 977985.

Brand-Williams, W.; Cuvelier, M. and Berset, C. (2000). Use of free radical method to evaluate antioxidant activity. Lebenson. Wiss. Technol., 28:25-30.

Broca, C.; Gross, R.; Petit, P.; Sauvaire, Y.; Manteghetti, M.; Tournier, M.; Masiello, P.; Gomis, R. and Ribes, G. (1999). 4-Hydroxyisoleucine: experimental evidence of its insulin tropic and antidiabetic properties. Am. J. Physiol. Endocrinol. Metab., 277 :617-623. 
Chen, A. Y. and Chen, Y.C. (2013). A review of the dietary flavonoid, kaempferol on human health and cancer chemoprevention. Food Chem., 138: 2099-2107.

Chen, H. J.; Lin, C.M.; Lee, C.Y.; Shih, N.C.; Peng, S.F.; Tsuzuki, M.; Amagaya, S.; Huang, W.W. and Yang, J.S. ( 2013). Kaempferol suppresses cell metastasis via inhibition of the ERK-p38-JNK and AP1 signaling pathways in U-2 OS human osteosarcoma cells. Oncol. Rep., 30: 925-932.

Doumas B. T. Watson W.A . and Biggs H.G., (1971): Albumin standards and the measurement of serum albumin with bromcresolgreen. Clin. Chem. Acta., 31:87-96

Efiong, E. E.; Igile, G. O.; Mgbeje, B. I. A.; Out, E. A. and Ebong, P. E. (2013). Hepatoprotective and anti-diabetic effect of combined extracts of Moringa oleifera and Vernonia amygdalina in streptozotocininduced diabetic albino Wistar rats. J. Diabetes Endocrinol., 4(4): 4550 .

Fabiny, D. and Eringhausen, G. (1971). Determination of serum creatinine. Clin. Chemistry, $17: 696$.

Fahey, J. W. (2005). A Review of the Medical Evidence for Its Nutritional, Therapeutic, and Prophylactic Properties. Part 1. Trees Life J., 1:5-15.

Fossati, P. and Principe, L. (1982). Serum triglyceride determined calorimetrically with enzyme that produces hydrogen peroxide. Clin. Chem., 28: 2077-2080.

Goupy, P.; Hugues, M.; Boivin, P. and Amiot, M. J.(1999). Antioxidant and activity of barley(Hordeum vulgare) and malt extracts and of isolated phenolic compound. J. Sci. Food Agric., 79:1625-1634.

Guy, P.A.; Renouf, M.; Barron, D.; Cavin, C.; Dionisi, F.; Kochhar, S.; Rezzi, S.; Williamson, G. and Steiling, H. (2009). Quantitative analysis of plasma caffeic and ferulic acid equivalents by liquid chromatography tandem mass spectrometry. J. Chrom. B: Anal. Technol. Biomed. Life Sci., 877: 3965-3974.

Ivanova, V.; Stefova, M. and Chinnici, N. (2010). Determination of the Polyphenol Content in Macedonian Grapes and Wines By Standardized Spectrophotometric Methods". J. Serbian Chem. Soc., 75(1)45-59. 
Kantarova, D.; Stuchluveloa, M.; Mokan, M. and Vrlile, M. (2006). Etiopathogensis of autoimmune diabetes mellitus in humans. Eur. J. Immunol., 31:102- 110.

Kaplan, M.L. and Murphy, S.D. (1972): Effects of acrylamide on rotarod performance and sciatic nerve betaglucoronidase activity of rats . Toxicol. Appl. Pharmacol., 22:259-268.

Kemelo, M.K.; Wojnarová, L.; Kutinovácanová, N. And Farghali, H. (2014). D-Galactosamine/Lipopolysaccharide-Induced Hepatotoxicity Downregulates Sirtuin 1 in Rat Liver: Role of Sirtuin 1 Modulation in Hepatoprotection. Physiol. Res., 63: 615-623.

Liu, L.M.; Zhang, J.X.; JIE, L.; Guoh, X.; Huan, D.; Chen, J.Y. and Sun, S.L (2008).A Role of Cell Apoptosis in Lipopolysaccharide (LPS)induced Nonlethal Liver Injury in D-galactosamine (D-GalN)-sensitized Rats. Digestive diseases and sciences vol. 53, no5, pp. 1316-1324.

Ndong, M.; Uhera, M.; Katsumata, S. and Suzuku, K. (2007). Effects of oral administration of Moringa oleifera Lam on Glucose Tolerance in GotoKakizaki and Wistar rats. J. Clin. Biochem. Nut., 40 (3):229-233.

NRC (1995). National Research Council. Nutrient Requirements Of Laboratory Animals. fourth revised edition, pp.29-30 National Academy Press. Washington, DC, USA.

Oluduro, A. O. (2012). Evaluation of antimicrobial properties and nutritional potentials of Moringa oleifera Lam. leaf in South Western Nigeria. Malays J. Microbiol , 8(2): 59-67.

Oyanatui, Y. (1984). Reevaluation of essay methods and establishments of kit for superoxide dismutase activity. Anal. Bio., 142:290-296.

Paget, G. F. and Barnes, J. M. (1964). Inter species dosages conversion scheme in evaluation for results and quantitative application in different species toxicity test. Academic press, London and NY.135-165.

Pakade, V.; Cukrowska, E. and Chimuka, L. (2013). Metal and flavonol contents of Moringa oleifera grown in South Africa. South Afr. J. Sci., 109:1-7

Pari, L. and Umamaheswari, J. (1999). Antihyperglycaemic activity of Musa sapeintum $L$. in alloxan-induced diabetic rats. $J$. Ethnopharmacol., 68: 1-5.

Pencock, C.A.; Schwartz, H.; Murphy, T.A. and Sellers, D. (1973): Evaluation of an enzymatic procedure for determination of serum glucose. Clin. Chem. Acta.,49:193. 
Pratik, K.C.; Vinodini, N.A.; Ranjith, S.; Rakshatha, R. and Anwar, A. (2013). Effect of Moringa oleifera leaf extract on cadmium induced renal toxicity in adult Wistar Albino rats. Int. J. Adv. Res., 1 (5); 162165.

Reitman, S. and Frankel, S. (1957). A colorimetric method for the determination of serum glutamic oxalooacetic and glutamic pyruvic transaminases. Am. J .Clin .Path., 28: 56-66.

Roeschlau, P.; Bernt, E. and Gruber, W. (1974). Enzymatic colorimetric test with lipid clearing factor (LCF). J. Clin.Chem. \& Clin. Biochem., 12:403-408.

Santos, Andréa F.; Adriana, C.; Argolo, I.; Patrícia, M. G. and Luana, C. B. (2012). Antioxidant Activity of Moringa Oleifera Tissue Extracts. Phytother. Res., 26: 1366-1370 .

Siest G., Henny J. and Schiele J. (1981). Determination enzymatique due glucose in Karger (ed). Interpretation des examens de laboratoire, 206223.

SPSS (2008). Statistical Package for Social Sciences Program, Version 17 for Windows, SPSS Inc., Chicago, IL, USA.

Sugunabai, J.; Jayaraj, M.; Karpagam, T. and Varalakshmi, B. (2014). Anti-diabetic efficiency of Moringa Oleifera and Solanum nigrum. Int. J. Pharm Sci., 6(1): 40-42.

Tabacco, A.; Meiattini, F. and Moda, E. ( 1979 ) : Simplified enzymic / colorimetric serum urea nitrogen determination . Clin. Chem., 25: 336-337.

Thiemermann, C.; Ruetten, H.; Wu, C.C. and Vane, J. R. (1995). The multiple organ dysfunction syndrome caused by endotoxin in the rat: attenuation of liver dysfunction by inhibitors of nitric oxide synthase. Br. J. Pharmacol., Dec. 1995, 116(7):2845-2851.

Wenger, C.; Kaplan, A.; Rubaitelli, F. and Hammerman, C. (1984). Determination of alkaline phosphatase in blood serum. Clin. Chemistry, 1094-1098.

Whittington, K. B.; Solomon, S. S. and Lu, Z. N. (1991). Islet allograft in the cryptorchid testes of spontaneously diabetic BB/W or dp rats: Response to glucose, glipizide and arginine. Endocrinol., 128: 2671-2677. 


\section{التاثير الواقي للمستخلص المائي لاوراق المورنيجا علي الكبا ومستوي سكر الام في حيوانات الاور التجارب}

جيهان علي غنيم - فاتن يوسف ابراهيم - رانيا ابراهيم الجمال قسم الصناعات الغذائية ـ كلية الزراعة ائن - جامعة المنصورة ـ مصر.

تهذف هذه الدراسة الي تقدير المحتوي الكلي للمواد الفينولية والفلافونيدية وتأثير

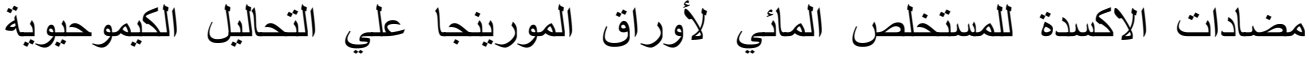

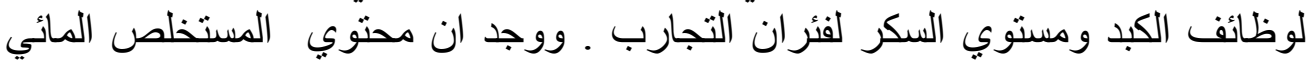

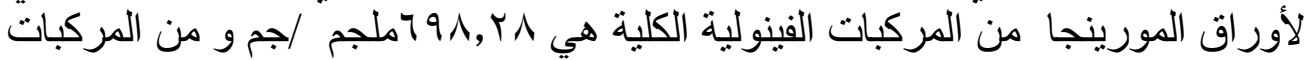

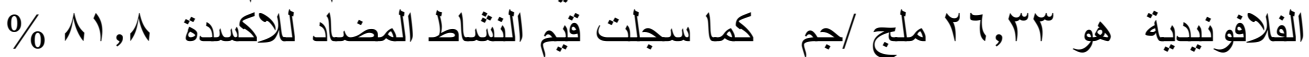

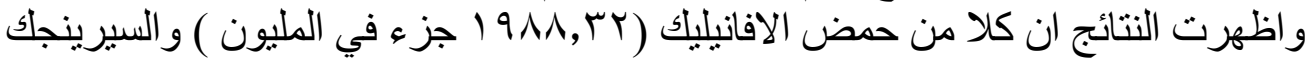

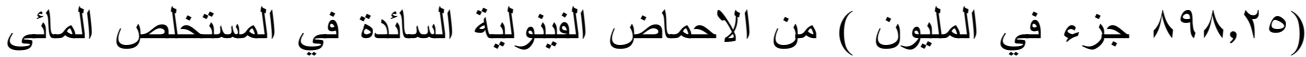

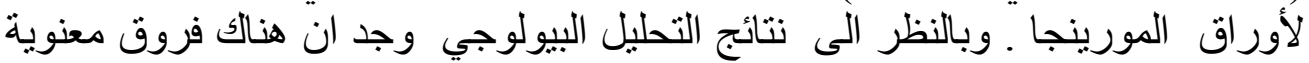

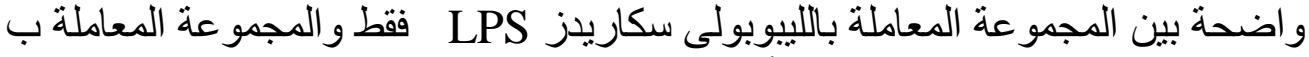

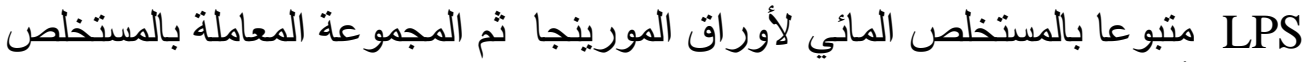

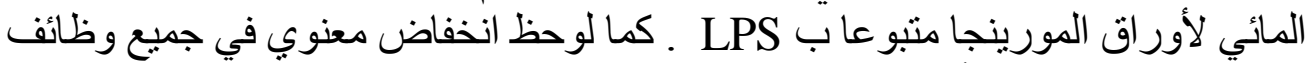

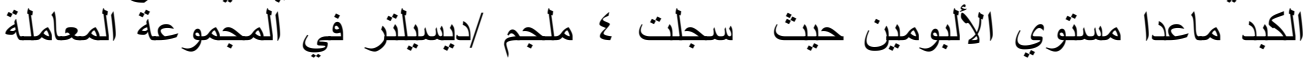

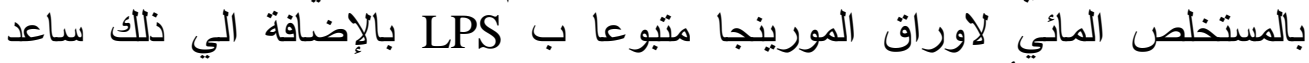
المستخلص المائي لأوراق المورينجا علي تحسين وظائف الكائي.

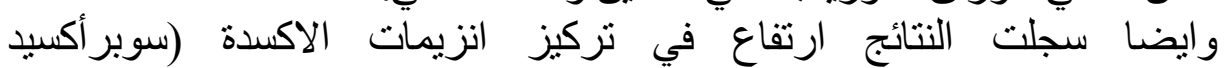

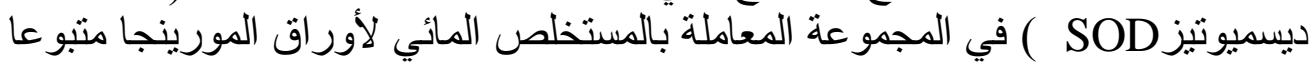

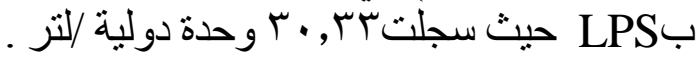
ومن ناحية اخري اعطت المجموعات المعاملة بالمستخلص المائي لاوراق المئ المورينجا

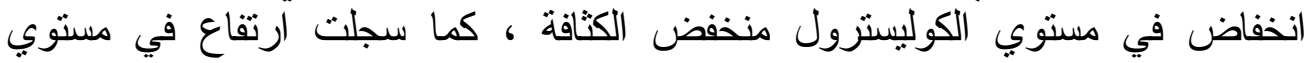

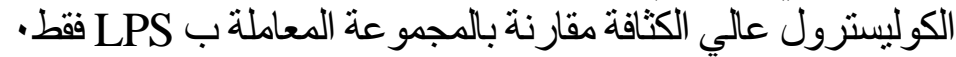

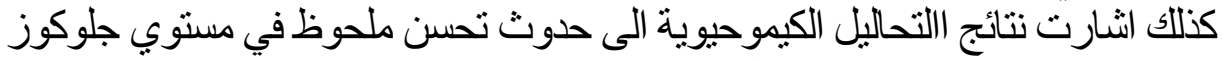

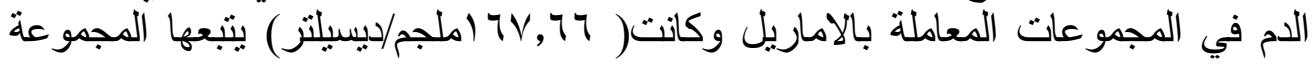

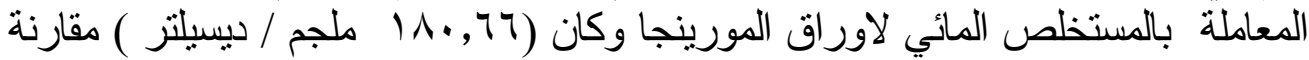

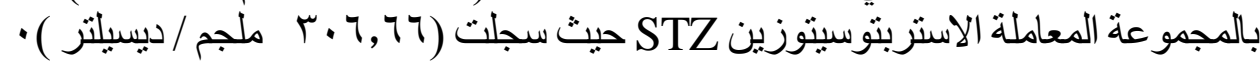

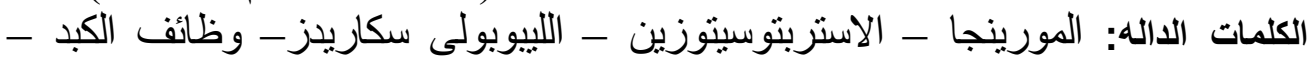
مرضى السكر. 